\title{
THE USE OF HOSPITALS BY A DEFINED POPULATION A COMMUNITY AND HOSPITAL STUDY IN NORTH LAMBETH
}

\author{
BY \\ J. W. PALMER*, B.A., Dip. S.A. \\ Lecturer \\ H. S. KASAP, A.I.S. \\ Lecturer \\ A. E. BENNETT, M.B., D.I.H. \\ Senior Lecturer \\ AND \\ W. W. HOLLAND, M.D., B.Sc. \\ Professor
}

Department of Clinical Epidemiology and Social Medicine, St. Thomas's Hospital Medical School, London, S.E.1

This present study is an attempt to estimate the hospital utilization of people living in a defined urban area. Results are presented of a house-tohouse enquiry into hospital usage. An attempt has been made to estimate the response errors of such an enquiry and to indicate how the results of a hospital survey by the Bailey method might be expected to differ from the results of a house-tohouse survey.

\section{METHODS}

A sample census of the population of North Lambeth was completed in the summer of 1966. Six electoral wards, comprising the northern part of the London Borough of Lambeth, were defined as the survey area. A high proportion of patients attending St. Thomas's Hospital had been shown to reside in this area (Bennett, 1966; Montgomery, 1968). A random sample of one in five of all private dwellings was provided by the General Register Office. This sample was drawn in the same way as the $10 \%$ sample for the national census and was arranged so that the two samples did not overlap. A census taker visited each dwelling and recorded the name, year of birth, and sex of each resident; in addition, a short questionnaire was completed for

-Present address: Housing Department, London Borough of Camden.

Request for reprints should be addressed to Professor W. W. Holland. all persons born in 1950 or earlier. The census was started on 4 July 1966 and continued intensively for two weeks; thereafter visiting was continued in order to make contact with households not seen during the main census period.

The questionnaire asked for information concerning the presence of certain specified disabilities and impairments, use of hospital services during 1966, occupation, age of leaving school, and civil (marital) state. The questionnaire was designed for self-administration but in many cases it was completed by the census taker in accordance with replies given by the person who answered the door. The only restriction placed on this was that proxy replies from persons who were not near relatives of the person enquired about were not accepted. We consider that the questions asked were of a sufficiently public and factual character to warrant this procedure.

The actual questions asked with regard to hospital services were:

Have you been to any kind of hospital as an OUT-PATIENT or CASUALTY since 1 January 1966? (YES or NO).............. If YES, please name the hospital or hospitals (1) $\ldots \ldots \ldots \ldots \ldots \ldots \ldots$ (2) (3) $\ldots \ldots \ldots \ldots \ldots \cdots \cdots \cdots \cdots \cdots$ Have you been a PATIENT IN A WARD of any kind of hospital since

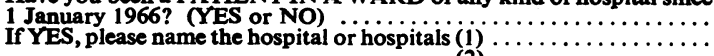
(3) $\ldots \ldots \ldots \ldots \cdots \cdots \cdots \cdots \cdots \cdots$

These questions were kept simple deliberately in order to make easier the task of completing the census, and it is not possible to infer the actual 
frequency of out-patient attendance or the duration of in-patient stays from the replies. The aim was to discover which hospitals were used by the population of the survey district.

\section{Analysis of House-to-House Census RESPONSES}

The sample of dwellings contained 5,546 addresses eligible for enumeration. Full information was obtained from 5,499 $(99 \cdot 2 \%)$ This yielded a population of 18,347 persons of whom 13,903 were born before 1 January 1951 and completed the questionnaire. Sufficient data were not obtained on six persons and these have been eliminated from the analyses which follow.

Table I shows the number of in-patient and outpatient mentions made by the persons enumerated. (The period enquired about was just over six months.). A 'mention' means that one person was shown by the questionnaire to have been a patient at one hospital. If a person attended the same hospital more than once, only one mention was counted, except that in- and out-patient usages were reckoned separately; thus a person who had been an in-patient and an out-patient at the same hospital was counted as having one in-patient mention and one out-patient mention. If a person was shown to have attended more than one hospital, one mention was counted for each hospital, even if the hospitals belonged to the same administrative group. Throughout this paper casualty services have been included in out- patient services, since it was felt that respondents could not be expected to distinguish between them.

It will be seen that older men use hospitals more than younger, whereas for women the highest inpatient usage is in the childbearing years. There is a trend towards more hospital usage by the lower social classes.

Table II shows the percentage distribution of mentions of hospitals, both out- and in-patient, between three groups of hospitals. The three groups are:

(a) the St. Thomas's administrative group (St. Thomas's, Royal Waterloo, General Lying-in, Grosvenor, Lambeth and Hydestile, which is St. Thomas's country branch);

(b) four other local hospitals which between them provide much of the remaining hospital services of the district (Westminster, Guy's, King's College, and the South London Hospital for Women and Children);

(c) all other hospitals, called 'peripheral' in the Table.

It can be seen that men use peripheral hospitals more than women. This may be due to their travelling more widely. The men who use peripherad hospitals most are those of social classes I and If and this may again be due to wider travel. Womeso seem to use peripheral hospitals more with increasing? age, this being especially true for in-patient facilities; the peripheral hospitals include many which cater specially for the aged.

TABLE I

NUMBERS OF MENTIONS OF HOSPITALS, IN CENSUS QUESTIONNAIRES, BY SEX, BY AGE AND SOCIAL CLASS*

\begin{tabular}{|c|c|c|c|c|c|c|}
\hline \multirow[b]{2}{*}{ Group } & \multirow{2}{*}{$\begin{array}{c}\text { No. of } \\
\text { Persons } \\
\text { Enumerated }\end{array}$} & \multirow[b]{2}{*}{$\begin{array}{c}\text { No. Replying } \\
\text { to } \\
\text { Hospital } \\
\text { Questions }\end{array}$} & \multicolumn{2}{|c|}{ Out-patient Mentions } & \multicolumn{2}{|c|}{ In-patient Mentions } \\
\hline & & & No. & $\begin{array}{l}\text { Per 100 } \\
\text { Persons } \\
\text { Replying }\end{array}$ & No. & $\begin{array}{c}\text { Per 100 } \\
\text { Persons } \\
\text { Replying }\end{array}$ \\
\hline $\begin{array}{c}\text { Men } 15-34 \\
35-54 \\
55+ \\
\end{array}$ & $\begin{array}{l}2,662 \\
2,303 \\
1,668 \\
\end{array}$ & $\begin{array}{l}2,657 \\
2,300 \\
1,665\end{array}$ & $\begin{array}{l}460 \\
387 \\
408 \\
\end{array}$ & $\begin{array}{l}17 \cdot 3 \\
16.8 \\
24.5\end{array}$ & $\begin{array}{r}81 \\
75 \\
147 \\
\end{array}$ & $\begin{array}{l}3 \cdot 0 \\
3 \cdot 3 \\
8 \cdot 8\end{array}$ \\
\hline $\begin{array}{c}\text { Women } 15-34 \\
35-54 \\
55+\end{array}$ & $\begin{array}{l}2,571 \\
2,441 \\
2,252\end{array}$ & $\begin{array}{l}2,567 \\
2,438 \\
2,245\end{array}$ & $\begin{array}{l}559 \\
508 \\
503\end{array}$ & $\begin{array}{l}21 \cdot 8 \\
20 \cdot 8 \\
22 \cdot 4\end{array}$ & $\begin{array}{l}274 \\
181 \\
130\end{array}$ & $\begin{array}{r}10.7 \\
7.4 \\
5.8\end{array}$ \\
\hline $\begin{array}{c}\text { Men S.C. I \& II } \\
\text { III \& V } \\
\text { IV \& V } \\
\text { Unclassifiable }\end{array}$ & $\begin{array}{r}603 \\
3,405 \\
2,341 \\
284\end{array}$ & $\begin{array}{r}602 \\
3,401 \\
2,337 \\
282\end{array}$ & $\begin{array}{r}108 \\
636 \\
466 \\
45\end{array}$ & $\begin{array}{l}17 \cdot 9 \\
18 \cdot 7 \\
19.9 \\
16 \cdot 0\end{array}$ & $\begin{array}{r}25 \\
153 \\
114 \\
11\end{array}$ & $\begin{array}{l}4 \cdot 2 \\
4 \cdot 5 \\
4 \cdot 9 \\
3 \cdot 9\end{array}$ \\
\hline 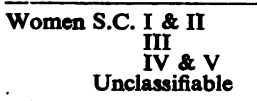 & $\begin{array}{r}637 \\
3,529 \\
2,707 \\
391\end{array}$ & $\begin{array}{r}635 \\
3,526 \\
2,703 \\
386\end{array}$ & $\begin{array}{r}136 \\
758 \\
607 \\
69\end{array}$ & $\begin{array}{l}21.4 \\
21.5 \\
22.5 \\
17.9\end{array}$ & $\begin{array}{r}51 \\
290 \\
221 \\
23\end{array}$ & $\begin{array}{l}8 \cdot 0 \\
8 \cdot 2 \\
8 \cdot 2 \\
6 \cdot 0\end{array}$ \\
\hline $\begin{array}{l}\text { All men } \\
\text { All women }\end{array}$ & $\begin{array}{l}6,633 \\
7,264\end{array}$ & $\begin{array}{l}6,622 \\
7,250\end{array}$ & $\begin{array}{l}1,255 \\
1,570\end{array}$ & $\begin{array}{l}19 \cdot 0 \\
21 \cdot 7\end{array}$ & $\begin{array}{l}303 \\
585\end{array}$ & $\begin{array}{l}4 \cdot 6 \\
8 \cdot 1\end{array}$ \\
\hline Both sexes & 13,897 & 13,872 & 2,825 & $20 \cdot 4$ & 888 & 6.4 \\
\hline
\end{tabular}

- Social class was determined according to the Registrar-General's (1966) classification of occupations. A married woman with a husband resident at the same address was assigned in the social class of the husband's occupation: all other persons were assigned to the social class o their own present (or, if not working, last) occupation. 
TABLB II

DISTRIBUTION OF MENTIONS AMONG HOSPITALS, BY SEX, BY AGE AND SOCIAL CLASS

\begin{tabular}{|c|c|c|c|c|c|c|c|c|}
\hline \multirow[b]{2}{*}{ Group } & \multicolumn{4}{|c|}{ Out-patients } & \multicolumn{4}{|c|}{ In-patients } \\
\hline & $\begin{array}{c}\text { No. of } \\
\text { Mentions } \\
(=100 \%)\end{array}$ & $\begin{array}{c}\text { St. } \\
\text { Thomas's } \\
\text { Group }\end{array}$ & $\begin{array}{l}\text { Four } \\
\text { Others }\end{array}$ & Peripheral & $\begin{array}{c}\text { No. of } \\
\text { Mentions } \\
(=100 \%)\end{array}$ & $\begin{array}{c}\text { St. } \\
\text { Thomas's } \\
\text { Group }\end{array}$ & $\begin{array}{l}\text { Four } \\
\text { Others }\end{array}$ & Peripheral \\
\hline $\begin{array}{c}\text { Men } 15-34 \\
35-54 \\
55+\end{array}$ & $\begin{array}{l}460 \\
387 \\
408\end{array}$ & $\begin{array}{l}53 \cdot 9 \\
61 \cdot 2 \\
65 \cdot 4\end{array}$ & $\begin{array}{l}19 \cdot 1 \\
16 \cdot 3 \\
12 \cdot 3\end{array}$ & $\begin{array}{l}26 \cdot 9 \\
22 \cdot 5 \\
22 \cdot 3\end{array}$ & $\begin{array}{r}81 \\
75 \\
147\end{array}$ & $\begin{array}{l}46.9 \\
44.0 \\
53.7\end{array}$ & $\begin{array}{l}21.0 \\
18.7 \\
10.9\end{array}$ & $\begin{array}{l}32 \cdot 1 \\
37 \cdot 3 \\
35 \cdot 4\end{array}$ \\
\hline 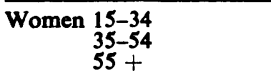 & $\begin{array}{l}559 \\
508 \\
503\end{array}$ & $\begin{array}{l}66 \cdot 9 \\
60 \cdot 4 \\
57 \cdot 5\end{array}$ & $\begin{array}{l}17 \cdot 0 \\
24 \cdot 0 \\
23 \cdot 3\end{array}$ & $\begin{array}{l}16 \cdot 1 \\
15 \cdot 6 \\
19 \cdot 3\end{array}$ & $\begin{array}{l}274 \\
181 \\
130\end{array}$ & $\begin{array}{l}68 \cdot 2 \\
51 \cdot 9 \\
53 \cdot 1\end{array}$ & $\begin{array}{l}11 \cdot 3 \\
24 \cdot 3 \\
16 \cdot 9\end{array}$ & $\begin{array}{l}20 \cdot 4 \\
23 \cdot 8 \\
30 \cdot 0\end{array}$ \\
\hline $\begin{array}{c}\text { Men S.C. I \& II } \\
\text { III \& V } \\
\text { IV \& V } \\
\text { Unclassified }\end{array}$ & $\begin{array}{r}108 \\
636 \\
466 \\
45\end{array}$ & $\begin{array}{l}55.6 \\
57.9 \\
63 \cdot 7 \\
60.0\end{array}$ & $\begin{array}{l}13 \cdot 0 \\
17 \cdot 1 \\
14 \cdot 6 \\
22 \cdot 2\end{array}$ & $\begin{array}{l}31 \cdot 5 \\
25 \cdot 0 \\
21 \cdot 7 \\
17 \cdot 8\end{array}$ & $\begin{array}{r}25 \\
153 \\
114 \\
11\end{array}$ & $\begin{array}{l}32 \cdot 0 \\
47 \cdot 7 \\
56 \cdot 1 \\
45 \cdot 5\end{array}$ & $\begin{array}{r}28 \cdot 0 \\
18 \cdot 3 \\
9 \cdot 6 \\
9 \cdot 1\end{array}$ & $\begin{array}{l}40 \cdot 0 \\
34 \cdot 0 \\
34 \cdot 2 \\
45 \cdot 5\end{array}$ \\
\hline $\begin{array}{r}\text { Women S.C. I \& II } \\
\text { III \& V } \\
\text { IV \&lassified }\end{array}$ & $\begin{array}{r}136 \\
758 \\
607 \\
69\end{array}$ & $\begin{array}{l}55 \cdot 9 \\
63 \cdot 1 \\
62 \cdot 9 \\
49 \cdot 3\end{array}$ & $\begin{array}{l}24 \cdot 3 \\
20 \cdot 1 \\
22 \cdot 1 \\
21 \cdot 7\end{array}$ & $\begin{array}{l}19.9 \\
16.9 \\
15.0 \\
29.0\end{array}$ & $\begin{array}{r}51 \\
290 \\
221 \\
23\end{array}$ & $\begin{array}{l}49 \cdot 0 \\
62 \cdot 8 \\
57.9 \\
65 \cdot 2\end{array}$ & $\begin{array}{r}19.6 \\
17.6 \\
15.4 \\
8.7\end{array}$ & $\begin{array}{l}19 \cdot 7 \\
19.7 \\
26.7 \\
26.1\end{array}$ \\
\hline $\begin{array}{l}\text { All men } \\
\text { All women }\end{array}$ & $\begin{array}{l}1,255 \\
1,570\end{array}$ & $\begin{array}{l}60 \cdot 0 \\
61 \cdot 8\end{array}$ & $\begin{array}{l}16 \cdot 0 \\
21 \cdot 3\end{array}$ & $\begin{array}{l}24 \cdot 1 \\
16.9\end{array}$ & $\begin{array}{l}303 \\
585\end{array}$ & $\begin{array}{l}49 \cdot 5 \\
59 \cdot 8\end{array}$ & $\begin{array}{l}15.5 \\
16.6\end{array}$ & $\begin{array}{l}35.0 \\
23.6\end{array}$ \\
\hline Both sexes & 2,825 & $61 \cdot 0$ & $18 \cdot 9$ & $20 \cdot 1$ & 888 & $56 \cdot 3$ & $16 \cdot 2$ & $27 \cdot 5$ \\
\hline
\end{tabular}

TABLE III

CLASSIFICATION OF PERSONS INTO 4 RESPONSE TYPES (AND 'NO REPLY') ACCORDING TO CENSUS REPLIES ON HOSPITAL USAGE: BY SEX, BY AGE AND SOCIAL CLASS

\begin{tabular}{|c|c|c|c|c|c|c|c|}
\hline \multirow[b]{2}{*}{ Group } & & \multirow{2}{*}{$\begin{array}{c}\text { No. } \\
\text { Enumerated }\end{array}$} & \multicolumn{5}{|c|}{ Per cent. } \\
\hline & & & No Reply & $\begin{array}{c}\text { No Hospital } \\
\text { Usage }\end{array}$ & $\begin{array}{l}\text { Out-patient } \\
\text { Only }\end{array}$ & $\begin{array}{l}\text { In-patient } \\
\text { Only }\end{array}$ & $\begin{array}{c}\text { Both Out- } \\
\text { and In-patient }\end{array}$ \\
\hline $\begin{array}{c}\text { Men } 15-34 \\
35-54 \\
55+\end{array}$ & & $\begin{array}{l}2,662 \\
2,303 \\
1,668\end{array}$ & $\begin{array}{l}0 \cdot 18 \\
0 \cdot 13 \\
0 \cdot 18\end{array}$ & $\begin{array}{l}81 \cdot 82 \\
82 \cdot 46 \\
72 \cdot 84\end{array}$ & $\begin{array}{l}15 \cdot 02 \\
14 \cdot 20 \\
18 \cdot 53\end{array}$ & $\begin{array}{l}0.68 \\
0.96 \\
2.82\end{array}$ & $\begin{array}{l}2.29 \\
2 \cdot 26 \\
5.64\end{array}$ \\
\hline $\begin{array}{c}\text { Women } 15-34 \\
35-54 \\
55+\end{array}$ & & $\begin{array}{l}2,571 \\
2,441 \\
2,252\end{array}$ & $\begin{array}{l}0.16 \\
0 \cdot 12 \\
0.31\end{array}$ & $\begin{array}{l}74.41 \\
77.02 \\
75.67\end{array}$ & $\begin{array}{l}14.90 \\
15.90 \\
18.52\end{array}$ & $\begin{array}{l}4.05 \\
2.21 \\
1 \cdot 78\end{array}$ & $\begin{array}{l}6.50 \\
4 \cdot 75 \\
3 \cdot 73\end{array}$ \\
\hline $\begin{array}{c}\text { Men S.C. I \& II } \\
\text { III } \\
\text { IV \& V } \\
\text { Unclassifiable }\end{array}$ & & $\begin{array}{r}603 \\
3,405 \\
2,341 \\
284\end{array}$ & $\begin{array}{l}0 \cdot 17 \\
0 \cdot 12 \\
0 \cdot 17 \\
0 \cdot 70\end{array}$ & $\begin{array}{l}80 \cdot 76 \\
80 \cdot 15 \\
78 \cdot 73 \\
82 \cdot 04\end{array}$ & $\begin{array}{l}14 \cdot 93 \\
15 \cdot 36 \\
16 \cdot 36 \\
14 \cdot 08\end{array}$ & $\begin{array}{l}1 \cdot 66 \\
1.23 \\
1.32 \\
1 \cdot 41\end{array}$ & $\begin{array}{l}2 \cdot 49 \\
3 \cdot 14 \\
3 \cdot 42 \\
1 \cdot 76\end{array}$ \\
\hline $\begin{array}{c}\text { Women S.C. I \& II } \\
\text { III } \& \text { V } \\
\text { Unclassifiable }\end{array}$ & 、 & $\begin{array}{r}637 \\
3,529 \\
2,707 \\
391\end{array}$ & $\begin{array}{l}0.31 \\
0.09 \\
0.15 \\
1.28\end{array}$ & $\begin{array}{l}74 \cdot 88 \\
76 \cdot 28 \\
74 \cdot 55 \\
79 \cdot 28\end{array}$ & $\begin{array}{l}16 \cdot 95 \\
15 \cdot 76 \\
17 \cdot 40 \\
13 \cdot 55\end{array}$ & $\begin{array}{l}3 \cdot 61 \\
2 \cdot 32 \\
3.07 \\
2.56\end{array}$ & $\begin{array}{l}4 \cdot 24 \\
5 \cdot 55 \\
4 \cdot 84 \\
3 \cdot 32\end{array}$ \\
\hline $\begin{array}{l}\text { All men } \\
\text { All women }\end{array}$ & & $\begin{array}{l}6,633 \\
7,264\end{array}$ & $\begin{array}{l}0 \cdot 17 \\
0 \cdot 19\end{array}$ & $\begin{array}{l}79.78 \\
75.67\end{array}$ & $\begin{array}{l}15.62 \\
16 \cdot 35\end{array}$ & $\begin{array}{l}1 \cdot 31 \\
2 \cdot 73\end{array}$ & $\begin{array}{l}3.12 \\
5.05\end{array}$ \\
\hline Both sexes & & 13,897 & $0 \cdot 18$ & $77 \cdot 64$ & $16 \cdot 00$ & 2.05 & $4 \cdot 13$ \\
\hline
\end{tabular}

Table III divides the respondents into four categories according to whether they stated that they were out-patients, in-patients, both or neither during the six-month period enquired about.

\section{Check on Accuracy of Reporting}

A stratified random sample was drawn of those who replied to the questionnaire: the strata were the four categories of reply indicated in Table III. The census replies of the sampled persons were checked against the hospital medical records. Records were searched for hospital experience occurring between 1 January 1966 and 10 July 1966-the latter being the estimated date by which $50 \%$ of the census questionnaires had been completed.

Table IV shows the way in which the sample for checking was drawn. The number of different hospitals mentioned in the census was very large, and it was completely impracticable to check the records of all hospitals mentioned. Even if this had been possible it would have provided no check against the possibility of a person being recorded as a patient at a hospital which had not been mentioned by any person in the census. Table II shows, however, that a large proportion of all hospital mentions were of 10 hospitals only, namely, the six 
TABLE IV

SHOWING METHOD OF SELECTING THE SAMPLE FOR CHECKING

\begin{tabular}{l|c|c|c}
\hline \multicolumn{1}{c|}{ Response Category } & $\begin{array}{c}\text { No. of } \\
\text { Persons } \\
\text { Enumerated }\end{array}$ & $\begin{array}{c}\text { Sampling } \\
\text { Fraction }\end{array}$ & $\begin{array}{c}\text { No. in } \\
\text { Check } \\
\text { Sample }\end{array}$ \\
\hline 'No reply' & 25 & 0 & 0 \\
'No hospital usage' & 10,789 & $1 / 50$ & 216 \\
'Out-patient only' & 2,224 & $1 / 20$ & 111 \\
'In-patient only' & 285 & $1 / 2$ & 141 \\
'Both out- and in-patient' & 574 & $1 / 5$ & 114 \\
\hline Total & 13,897 & & 582 \\
\hline
\end{tabular}

members of the St. Thomas's Group and the four other local hospitals named in the previous section. All persons in the check sample were looked for in the medical records of these 10 hospitals: enquiry was made at other hospitals only for those members of the check sample who mentioned them in their questionnaires.

It should be noted that recorded hospital usage is likely to be underestimated by the procedure adopted, since not all persons were looked for in the medical records of the peripheral hospitals. There is, therefore, an inherent bias towards 'overreporting' or 'under-recording', but only at the peripheral hospitals.

Table $\mathrm{V}$ shows how the members of the check sample were reclassified as a result of the search of hospital records. The percentage who replied correctly varied from $96 \%$ of those who asserted no hospital use to only $18 \%$ of those who said they had been in-patients only. It can be seen that the greatest number of the latter were shown by medical records also to have been out-patients. The general tendency, however, is for more hospital experience to be reported than recorded.

TABLE V

RECLASSIFICATION OF CHECK SAMPLE NUMBERS AS A RESULT OF RECORDS SEARCH

\begin{tabular}{|c|c|c|c|c|c|c|}
\hline \multirow[b]{2}{*}{$\begin{array}{c}\text { Census } \\
\text { Statement }\end{array}$} & \multicolumn{5}{|c|}{ Records } & \multirow[b]{2}{*}{$\begin{array}{l}\text { Per cent. } \\
\text { Correct }\end{array}$} \\
\hline & None & Out & In & $\begin{array}{l}\text { Out } \\
\text { and in }\end{array}$ & Total & \\
\hline $\begin{array}{l}\text { No hospital use } \\
\text { Out-patient only } \\
\text { In-patient only } \\
\text { Both out and in }\end{array}$ & $\begin{array}{r}207 \\
43 \\
37 \\
15\end{array}$ & $\begin{array}{r}8 \\
65 \\
11 \\
14\end{array}$ & $\begin{array}{r}0 \\
1 \\
25 \\
12\end{array}$ & $\begin{array}{r}1 \\
2 \\
68 \\
73\end{array}$ & $\begin{array}{l}216 \\
111 \\
141 \\
114\end{array}$ & $\begin{array}{l}95 \cdot 83 \\
58 \cdot 56 \\
17 \cdot 73 \\
64 \cdot 04\end{array}$ \\
\hline
\end{tabular}

Bailey (1956) described a method for defining the population served by a hospital, or group of hospitals, and this was used in the Northampton and Norwich studies (Nuffield Provincial Hospitals Trust, 1955) and the Barrow and Furness study (Forsyth and Logan, 1960). A survey is made of admissions to all hospitals in the area of the study, recording over a period of time the place of residence of patients admitted. Hospitals surveyed must include all those which by reason of nearness or convenience admit a significant number of patients from the catchment area of the hospital principally studied. The ratio of the number of admissions to the principal hospital to the total number of hospital admissions experienced by the population of the area is then calculated. Thus, if the population of a given district is $N$, the number of persons admitted from that district to the principal hospital $a$, and the number of persons admitted to other hospitals $b$; then the population of that area served by the principal hospital is $N \frac{a}{a+b}$.

This method assumes that $\frac{a}{a+b}$ is an accurate measure of the proportion of the population of a district served by the principal hospital. However, $a+b$ is not the ideal denominator in this formula; to it should be added $c$, the number of persons from the district admitted to hospitals other than those included in the survey; otherwise, since $\frac{a}{a+b}$ is larger than $\frac{a}{a+b+c}$, the effective population served by the principal hospital is over-estimated. In certain conditions it is reasonable to ignore $c$ as being very small. Such conditions prevail where the district being considered is geographically isolated. However, if it is part of an urban area with good communications, $c$ may be of considerable size.

There are two methods of dealing with this problem. One is to increase the number of hospitals surveyed (ideally until all hospitals in an area are included), thus moving some admissions out of the category $c$ into $b$. The other is to obtain a direct value for $a+b+c$ by obtaining information from the people of a district rather than from the hospitals. However, information obtained in the latter way will be subject to reporting errors.

In Table VI the figures of Table $V$ have been multiplied by the reciprocal of the sampling fraction for each stratum of the sub-sample, to yield estimates of the numbers correctly classified and misclassified in the total enumerated population. The percentages in the right-hand column give the distribution according to the census replies, and in the bottom row the estimated distribution according to medical records. The net tendency is clearly towards overreporting or under-recording of hospital experience. 
TABLE VI

SHOWING ESTIMATION OF 'TRUE' HOSPITAL EXPERIENCE (i.e. INDICATED BY MEDICAL RECORDS) OF CENSUS POPULATION

\begin{tabular}{|c|c|c|c|c|c|c|c|}
\hline \multirow{2}{*}{ Report } & \multicolumn{5}{|c|}{ Records } & \multirow{2}{*}{ Total } & \multirow{2}{*}{ Per cent. } \\
\hline & None & Out & In & Out and In & No Reply & & \\
\hline $\begin{array}{l}\text { No hospital use } \\
\text { Out-patient only } \\
\text { In-patient only } \\
\text { Both out and in } \\
\text { No reply }\end{array}$ & $\begin{array}{r}10,339 \\
862 \\
75 \\
76\end{array}$ & $\begin{array}{r}400 \\
1,302 \\
22 \\
70\end{array}$ & $\begin{array}{l}0 \\
20 \\
51 \\
60\end{array}$ & $\begin{array}{r}50 \\
40 \\
137 \\
368\end{array}$ & 25 & $\begin{array}{r}10,789 \\
2,224 \\
285 \\
574 \\
25\end{array}$ & $\begin{array}{r}77 \cdot 64 \\
16.00 \\
2.05 \\
4 \cdot 13 \\
0.18\end{array}$ \\
\hline Total & 11,352 & 1,794 & 131 & 595 & 25 & 13,897 & 100 \\
\hline$\overline{\%}$ & 81.69 & 12.90 & 0.94 & $4 \cdot 28$ & 0.18 & $100^{\circ}$ & \\
\hline
\end{tabular}

TABLE VII

DISTRIBUTION OF MENTIONS BETWEEN HOSPITALS: ACTUAL CENSUS REPLIES AND ESTIMATED RECORDS

\begin{tabular}{|c|c|c|c|c|}
\hline & \multicolumn{2}{|c|}{ Out-patients } & \multicolumn{2}{|c|}{ In-patients } \\
\hline & $\begin{array}{l}\text { Census } \\
\text { Replies }\end{array}$ & $\begin{array}{c}\text { Records } \\
\text { (Est.) }\end{array}$ & $\begin{array}{l}\text { Census } \\
\text { Replies }\end{array}$ & $\begin{array}{c}\text { Records } \\
\text { (Est.) }\end{array}$ \\
\hline \multirow{2}{*}{$\begin{array}{l}\text { St. Thomas's } \\
\text { Group } \\
4 \text { other hospitals } \\
\text { Peripheral } \\
\text { hospitals }\end{array}$} & $\begin{array}{r}1,722 \\
535\end{array}$ & $\begin{array}{r}1,676 \\
657\end{array}$ & $\begin{array}{l}500 \\
144\end{array}$ & $\begin{array}{l}470 \\
109\end{array}$ \\
\hline & 568 & 225 & 244 & 179 \\
\hline All hospitals & 2,825 & 2,558 & 888 & 758 \\
\hline
\end{tabular}

In Table VII the numbers of report mentions of hospitals in three groups are compared with the numbers of record mentions as estimated by multiplying up from the sub-sample. Out-patient and in-patient mentions are treated separately. It is clear that the tendency to over-report (or underrecord) is not confined to the peripheral hospitals, although, as expected because of the design of the checking procedure, it is most marked in these hospitals.

The very great discrepancy between the census and estimated record figures for out-patients at peripheral hospitals is probably due to a different shortcoming of the design. The records of the St. Thomas's Group and the 'other four' hospitals were searched by the staff of this Department, but at the peripheral hospitals the search was carried out by their own medical records staff. It seems likely that the latter sometimes reported a person as having been 'in-patient only' and omitted to report the fact that he had also been an out-patient, thus giving a misleadingly low estimate of out-patient usage at these hospitals.

Over-reporting on the questionnaires may be due to respondents reporting hospital episodes which actually took place before the period covered by the enquiry, i.e., before 1 January 1966. However, this does not seem to explain all over-reporting; in Table VIII all mentions of hospitals on the ques- tionnaires are divided into those confirmed from records, confirmed but prior to 1966 , and not confirmed; it is clear that the greater part of overreporting is not due to failure to recall the dates of hospital episodes.

Table IX shows how the accuracy of reporting varies with sex, age, and social class. The hospital experience of men is better reported than that of women; that of social classes I and II is better reported than that of other classes. Older women's experience seems to be less accurately reported than

TABLE VIII

MENTIONS OF HOSPITALS FROM QUESTIONNAIRES: PR OPORTIONS CONFIRMED, CONFIRMED BUT BEFORE 1/1/66, AND NOT CONFIRMED

(Estimates from check sample adjusted to enumerated population)

\begin{tabular}{l|c|c|c|c}
\hline & - & \multicolumn{3}{|c}{ Per cent. } \\
\hline & $\begin{array}{c}\text { Confirmed } \\
\text { from } \\
\text { Records }\end{array}$ & $\begin{array}{c}\text { Confirmed } \\
\text { from } \\
\text { Records } \\
\text { but } \\
\text { Before } \\
1 / 1 / 66\end{array}$ & $\begin{array}{c}\text { Not } \\
\text { Confirmed } \\
\text { from } \\
\text { Records }\end{array}$ & Total \\
\hline $\begin{array}{c}\text { Out-patient } \\
\text { mentions } \\
\begin{array}{c}\text { In-patient } \\
\text { mentions }\end{array}\end{array}$ & 62.17 & 15.80 & 22.03 & 100 \\
\hline & 69.28 & 10.63 & 20.09 & 100 \\
\hline
\end{tabular}

TABLE IX

ACCURACY OF REPORTING, BY SEX, BY AGE AND SOCIAL CLASS

(Strata combined and adjusted to total enumerated population)

\begin{tabular}{l|c|c}
\hline & \multicolumn{2}{|c}{ Per cent. in Correct Response } \\
& \multicolumn{2}{|c}{ Category } \\
\cline { 2 - 3 } & Men & Women \\
\hline Age 15-34 & 89.0 & 86.6 \\
55-54 & 88.4 & 88.3 \\
Social class I \& II & 90.9 & 80.4 \\
\hline III \& V & 97.8 & 94.0 \\
Unclassifiable & 88.9 & 85.3 \\
\hline All ages and social classes & 97.3 & 84.8 \\
Both sexes & 89.9 & 73.6 \\
\hline
\end{tabular}


TABLE X

NUMBERS OF MENTIONS OF HOSPITALS, CORRECTED FOR RESPONSE ERRORS, BY SEX, AGE AND SOCIAL CLASS

\begin{tabular}{|c|c|c|c|c|c|c|}
\hline \multirow[b]{2}{*}{ Group } & \multirow[b]{2}{*}{$\begin{array}{c}\text { Persons } \\
\text { Enumerated }\end{array}$} & \multirow[b]{2}{*}{$\begin{array}{c}\text { No. Replying } \\
\text { to } \\
\text { Hospital } \\
\text { Questions }\end{array}$} & \multicolumn{2}{|c|}{ Out-patient Mentions } & \multicolumn{2}{|c|}{ In-patient Mentions } \\
\hline & & & No. & $\begin{array}{c}\text { Per 100 } \\
\text { Persons } \\
\text { Replying }\end{array}$ & No. & $\begin{array}{c}\text { Per } 100 \\
\text { Persons } \\
\text { Replying }\end{array}$ \\
\hline $\begin{array}{c}\text { Men 15-34 } \\
35-54 \\
55+\end{array}$ & $\begin{array}{l}2,662 \\
2,303 \\
1,668\end{array}$ & $\begin{array}{l}2,657 \\
2,300 \\
1,665\end{array}$ & $\begin{array}{l}325 \\
310 \\
318\end{array}$ & $\begin{array}{l}12.2 \\
13.5 \\
19.1\end{array}$ & $\begin{array}{r}63 \\
85 \\
110\end{array}$ & $\begin{array}{l}2.4 \\
3.7 \\
6.6\end{array}$ \\
\hline 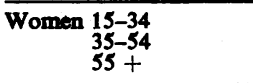 & $\begin{array}{l}2,571 \\
2,441 \\
2,252\end{array}$ & $\begin{array}{l}2,567 \\
2,438 \\
2,245\end{array}$ & $\begin{array}{l}639 \\
420 \\
479\end{array}$ & $\begin{array}{l}24.9 \\
17.2 \\
21.3\end{array}$ & $\begin{array}{r}243 \\
109 \\
85\end{array}$ & $\begin{array}{l}9.5 \\
4.5 \\
3.8\end{array}$ \\
\hline $\begin{array}{c}\text { Men S.C. I \& II } \\
\text { II \& V V } \\
\text { Unclassifiable }\end{array}$ & $\begin{array}{r}603 \\
3,405 \\
2,341 \\
284\end{array}$ & $\begin{array}{r}602 \\
3,401 \\
2,337 \\
282\end{array}$ & $\begin{array}{r}73 \\
491 \\
356 \\
33\end{array}$ & $\begin{array}{l}12 \cdot 1 \\
14.4 \\
15 \cdot 2 \\
11 \cdot 7\end{array}$ & $\begin{array}{r}14 \\
158 \\
82 \\
4\end{array}$ & $\begin{array}{l}2 \cdot 3 \\
4 \cdot 6 \\
3 \cdot 5 \\
1 \cdot 4\end{array}$ \\
\hline $\begin{array}{r}\text { Women S.C. I \& II } \\
\text { III \& V V } \\
\text { Unclassifiable }\end{array}$ & $\begin{array}{r}637 \\
3,529 \\
2,707 \\
391\end{array}$ & $\begin{array}{l}635 \\
3,526 \\
2,703 \\
386\end{array}$ & $\begin{array}{l}125 \\
754 \\
544 \\
115\end{array}$ & $\begin{array}{l}19 \cdot 7 \\
21 \cdot 4 \\
20.1 \\
29 \cdot 8\end{array}$ & $\begin{array}{r}29 \\
193 \\
200 \\
15\end{array}$ & $\begin{array}{l}4.6 \\
5.5 \\
7.4 \\
3.9\end{array}$ \\
\hline $\begin{array}{l}\text { All men } \\
\text { All women }\end{array}$ & $\begin{array}{l}6,633 \\
7,264\end{array}$ & $\begin{array}{l}6,622 \\
7,250\end{array}$ & $\begin{array}{r}975 \\
1,549\end{array}$ & $\begin{array}{l}14 \cdot 7 \\
21 \cdot 4\end{array}$ & $\begin{array}{l}278 \\
474\end{array}$ & $\begin{array}{l}4.2 \\
6.5\end{array}$ \\
\hline Both sexes & 13,897 & 13,872 & 2,558 & $18 \cdot 4$ & 758 & 5.5 \\
\hline
\end{tabular}

TABLE XI

DISTRIBUTION OF MENTIONS AMONG HOSPITALS: CENSUS RESPONSES AND CORRECTED ESTIMATES

\begin{tabular}{|c|c|c|c|c|c|c|c|c|}
\hline \multirow[b]{2}{*}{ Group } & \multicolumn{4}{|c|}{ Out-patients } & \multicolumn{4}{|c|}{ In-patients } \\
\hline & $\begin{array}{c}\text { No. of } \\
\text { Mentions }\end{array}$ & $\begin{array}{l}\text { St. Thomas's } \\
\text { Group }\end{array}$ & $\begin{array}{l}\text { Four } \\
\text { Others }\end{array}$ & Peripheral & $\begin{array}{c}\text { No. of } \\
\text { Mentions }\end{array}$ & $\begin{array}{l}\text { St. Thomas's } \\
\text { Group }\end{array}$ & $\begin{array}{l}\text { Four } \\
\text { Others }\end{array}$ & Peripheral \\
\hline $\begin{array}{c}\text { All men } \\
\text { Census } \\
\text { Corrected No. } \\
\begin{array}{c}\text { No. } \\
\%\end{array} \\
\end{array}$ & $\begin{array}{r}1,255 \\
100 \\
975 \\
100 \\
\end{array}$ & $\begin{array}{l}752 \\
60.0 \\
600 \\
61 \cdot 5\end{array}$ & $\begin{array}{r}201 \\
16.0 \\
272 \\
27.9\end{array}$ & $\begin{array}{r}302 \\
24.1 \\
103 \\
10.6 \\
\end{array}$ & $\begin{array}{l}303 \\
100 \\
278 \\
100\end{array}$ & $\begin{array}{r}150 \\
49 \cdot 5 \\
138 \\
49 \cdot 6\end{array}$ & $\begin{array}{r}47 \\
15.5 \\
47 \\
16.9\end{array}$ & $\begin{array}{c}106 \\
35.0 \\
93 \\
33 \cdot 5\end{array}$ \\
\hline $\begin{array}{c}\begin{array}{c}\text { All women } \\
\text { Census } \\
\text { Corrected No. } \\
\text { No. } \\
\%\end{array} \\
\end{array}$ & $\begin{array}{r}1,570 \\
100 \\
1,549 \\
100\end{array}$ & $\begin{array}{l}970 \\
61.8 \\
1,050 \\
67.8 \\
\end{array}$ & $\begin{array}{r}334 \\
21.3 \\
378 \\
24 \cdot 4 \\
\end{array}$ & $\begin{array}{r}266 \\
16.9 \\
121 \\
7.8 \\
\end{array}$ & $\begin{array}{l}585 \\
100 \\
474 \\
100\end{array}$ & $\begin{array}{r}350 \\
59.8 \\
331 \\
69.8\end{array}$ & $\begin{array}{r}97 \\
16 \cdot 6 \\
61 \\
12 \cdot 9\end{array}$ & $\begin{array}{r}138 \\
23.6 \\
82 \\
17 \cdot 3\end{array}$ \\
\hline $\begin{array}{c}\text { Both sexes } \\
\text { Census } \\
\text { Corrected } \\
\% \\
\%\end{array}$ & $\begin{array}{r}2,825 \\
2,550 \\
100\end{array}$ & $\begin{array}{r}1,722 \\
61 \cdot 0 \\
1,676 \\
65 \cdot 5\end{array}$ & $\begin{array}{r}535 \\
18.9 \\
657 \\
25.7\end{array}$ & $\begin{array}{r}568 \\
20.1 \\
225 \\
8.8\end{array}$ & $\begin{array}{r}888 \\
100 \\
758 \\
\cdot 100\end{array}$ & $\begin{array}{r}500 \\
56 \cdot 3 \\
470 \\
62.0\end{array}$ & $\begin{array}{c}144 \\
16 \cdot 2 \\
109 \\
14.4\end{array}$ & $\begin{array}{r}244 \\
27.5 \\
179 \\
23 \cdot 6\end{array}$ \\
\hline
\end{tabular}

younger women's, but there is no such tendency among men.

Revised Estimates of Hospital Usage.-As a result of the checking, it is now possible to calculate what responses would have been obtained in the census if all persons had given replies in accordance with their actual hospital usage as found from medical records. This is done, as before, by multiplying the medical records findings for each stratum of the check sample by the reciprocal of the sampling fraction for that stratum and summing over all four strata. Tables X to XII have been produced in this way.

Table $\mathrm{X}$ is a repetition of Table $\mathrm{I}$ except that the numbers of hospital mentions and the numbers per.
100 persons have been corrected for the errors found by the checking procedure. (The numbers of mentions are not strictly additive; this is due to rounding errors in the process of estimation.)

Table XI repeats the bottom three lines of Table II (for all men, all women, and both sexes) and gives the corrected estimates for redistribution of mentions between hospitals. The notable shift away from peripheral hospitals produced by the correction may be due in part to the shortcomings of the design referred to above. The tendency for men to use peripheral hospitals more than women remains when the correction is applied.

Table XII repeats Table III but is again corrected for response error.

The conclusions as regards differences between 
TABLE XII

CLASSIFICATION OF PERSONS INTO 4 RESPONSE GROUPS (AND 'NO REPLY') CORRECTED ACCORDING TO ERRORS FOUND IN CHECK SAMPLE: BY SEX, AGE AND SOCIAL CLASS

\begin{tabular}{|c|c|c|c|c|c|c|}
\hline \multirow[b]{2}{*}{ Group } & \multirow{2}{*}{$\begin{array}{c}\text { No. } \\
\text { Enumerated }\end{array}$} & \multicolumn{5}{|c|}{ Per cent. } \\
\hline & & No Reply & $\begin{array}{c}\text { No Hospital } \\
\text { Usage }\end{array}$ & $\begin{array}{l}\text { Out-patient } \\
\text { Only }\end{array}$ & $\begin{array}{l}\text { In-patient } \\
\text { Only }\end{array}$ & $\begin{array}{l}\text { Both Out- and } \\
\text { In-patient }\end{array}$ \\
\hline $\begin{array}{c}\text { Men } 15-34 \\
35-54 \\
55+\end{array}$ & $\begin{array}{l}2,662 \\
2,303 \\
1,668\end{array}$ & $\begin{array}{l}0 \cdot 18 \\
0 \cdot 13 \\
0 \cdot 18\end{array}$ & $\begin{array}{l}87.98 \\
84.59 \\
78.90\end{array}$ & $\begin{array}{r}9 \cdot 73 \\
11.55 \\
14 \cdot 21\end{array}$ & $\begin{array}{l}0.26 \\
1.00 \\
2 \cdot 22\end{array}$ & $\begin{array}{l}1 \cdot 84 \\
2 \cdot 74 \\
4 \cdot 50\end{array}$ \\
\hline 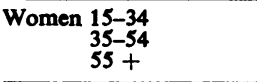 & $\begin{array}{l}2,571 \\
2,441 \\
2,252\end{array}$ & $\begin{array}{l}0 \cdot 16 \\
0 \cdot 12 \\
0 \cdot 31\end{array}$ & $\begin{array}{l}76 \cdot 31 \\
83 \cdot 33 \\
77 \cdot 89\end{array}$ & $\begin{array}{l}14 \cdot 20 \\
12 \cdot 17 \\
17 \cdot 58\end{array}$ & $\begin{array}{l}0 \cdot 51 \\
0 \cdot 20 \\
2 \cdot 18\end{array}$ & $\begin{array}{l}8 \cdot 83 \\
4 \cdot 18 \\
2 \cdot 04\end{array}$ \\
\hline $\begin{array}{c}\text { Men S.C. I \& II } \\
\text { III \& V } \\
\text { Unclassifiable }\end{array}$ & $\begin{array}{r}603 \\
3,405 \\
2,341 \\
284\end{array}$ & $\begin{array}{l}0 \cdot 17 \\
0 \cdot 12 \\
0 \cdot 17 \\
0 \cdot 70\end{array}$ & $\begin{array}{l}81 \cdot 09 \\
85 \cdot 34 \\
83 \cdot 72 \\
88 \cdot 38\end{array}$ & $\begin{array}{r}14 \cdot 93 \\
10 \cdot 19 \\
12 \cdot 82 \\
8 \cdot 80\end{array}$ & $\begin{array}{l}1.49 \\
0.70 \\
1.32 \\
1.06\end{array}$ & $\begin{array}{l}2.32 \\
3.64 \\
1.96 \\
1.06\end{array}$ \\
\hline Women S.C. I \& II $\operatorname{III}_{\substack{\text { IV \& V } \\
\text { Unclassifiable }}}$ & $\begin{array}{r}637 \\
3,529 \\
2,707 \\
391\end{array}$ & $\begin{array}{l}0.31 \\
0.09 \\
0.15 \\
1.28\end{array}$ & $\begin{array}{l}78 \cdot 34 \\
80 \cdot 65 \\
78 \cdot 98 \\
68 \cdot 29\end{array}$ & $\begin{array}{l}16 \cdot 01 \\
13 \cdot 97 \\
13 \cdot 30 \\
26 \cdot 34\end{array}$ & $\begin{array}{l}0.62 \\
0.57 \\
1.44 \\
1.02\end{array}$ & $\begin{array}{l}4 \cdot 71 \\
4.73 \\
6.13 \\
3.07\end{array}$ \\
\hline $\begin{array}{l}\text { All men } \\
\text { All women }\end{array}$ & $\begin{array}{l}6,633 \\
7,264\end{array}$ & $\begin{array}{l}0 \cdot 17 \\
0 \cdot 19\end{array}$ & $\begin{array}{l}84 \cdot 52 \\
79 \cdot 16\end{array}$ & $\begin{array}{l}11.49 \\
14.56\end{array}$ & $\begin{array}{l}1.01 \\
0.92\end{array}$ & $\begin{array}{l}2 \cdot 81 \\
5 \cdot 16\end{array}$ \\
\hline Both sexes & 13,897 & 0.18 & 81.69 & 12.90 & 0.94 & $4 \cdot 28$ \\
\hline
\end{tabular}

TABLE XIII

DISTRIBUTION OF MENTIONS AMONG HOSPITALS: CENSUS RESPONSES AND CORRECTED ESTIMATES

\begin{tabular}{|c|c|c|c|c|c|c|c|c|c|}
\hline & & \multicolumn{4}{|c|}{ Out-patients } & \multicolumn{4}{|c|}{ In-patients } \\
\hline & & \multicolumn{2}{|c|}{ Census } & \multicolumn{2}{|c|}{ Corrected } & \multicolumn{2}{|c|}{ Census } & \multicolumn{2}{|c|}{ Corrected } \\
\hline & & No. & $\%$ & No. & $\%$ & No. & $\%$ & No. & $\%$ \\
\hline \multirow{4}{*}{$\begin{array}{l}\text { Both } \\
\text { Sexes }\end{array}$} & \multirow{4}{*}{$\begin{array}{l}a=\text { St. Thomas's Group } \\
b=\left\{\begin{array}{l}4 \text { other hospitals } \\
\text { All other hospitals in } \\
\text { the } 93\end{array}\right. \\
c=\text { Others (not surveyed } \\
\text { by Bailey method) }\end{array}$} & 1,722 & $61 \cdot 0$ & 1,676 & $65 \cdot 5$ & 500 & $56 \cdot 3$ & 470 & $62 \cdot 0$ \\
\hline & & 535 & 18.9 & 657 & $25 \cdot 7$ & 144 & $16 \cdot 2$ & 109 & $14 \cdot 4$ \\
\hline & & 458 & $16 \cdot 2$ & $181^{*}$ & $7 \cdot 1 *$ & 177 & $19 \cdot 9$ & $130 *$ & $17 \cdot 2 *$ \\
\hline & & 110 & 3.9 & $44^{*}$ & $1.7 *$ & 67 & $7 \cdot 5$ & 49* & $6.5^{*}$ \\
\hline \multicolumn{2}{|l|}{ Total } & 2,825 & 100 & 2,558 & 100 & 888 & 100 & 758 & 100 \\
\hline
\end{tabular}

-Estimated as an equivalent proportion of mentions at peripheral hospitals to that found in the census.

groups to be drawn from Tables I to III are scarcely affected by the corrections: the generally lower degree of usage after correction, however, is clear.

Estimated Results of THE BaIley Method.Table XI shows that $56.3 \%$ of the hospital in-patient usage in the area of study is in the St. Thomas's Group. The denominator for this percentage is the total hospital usage of the sample of people in the area, and the numerator that part of the usage which was at St. Thomas's. This percentage thus corresponds to the calculation of $\frac{a}{a+b+c}$.

If a survey had been conducted by the Bailey method, $a$ would have been correctly estimated from St. Thomas's medical records. The accuracy of estimation of $b+c$ would depend on how large $b$ was in relation to $c$; the larger the number of hospitals surveyed, the more accurate the estimate of $b+c$.

If only 10 hospitals - the St. Thomas's Group and the 'four other local hospitals'-were surveyed, then (Table VII) $a=500, b=144$, and $\frac{a}{a+b}=77 \cdot 6 \%$.

Thus $77.6 \%$ of the population of the district would have been included in the effective population served by the hospital, whereas the results obtained show $56.3 \%$. If the corrected figures are used in this calculation the results are $81.2 \%$ as opposed to $62.0 \%$.

However, such a survey should not be restricted to only 10 hospitals. A survey would have included all hospitals in the London Borough of Lambeth, Southwark, and Wandsworth, or on their borders, with all London teaching hospitals and their associated hospitals, giving 93 hospitals in all 
(excluding children's hospitals). Table XIII shows the distribution of hospital mentions found between hospitals, distinguishing these 93 hospitals from others. Therefore it is possible to compare estimates derived by the two methods of the contribution which the area of study makes to the total population served by St. Thomas's (Table XIV). The constant 5 allows for the fact that the census was a $20 \%$ sample; children and institutional residents are excluded. These figures give a measure of the magnitude of the differences in results obtained by a household survey and the Bailey method.

TABLE XIV

\begin{tabular}{|c|c|c|c|c|}
\hline & \multicolumn{4}{|c|}{ Mentions } \\
\hline & \multicolumn{2}{|c|}{ Out-patients } & \multicolumn{2}{|c|}{ In-patients } \\
\hline & Census & $\begin{array}{l}\text { Cor- } \\
\text { rected }\end{array}$ & Census & $\begin{array}{l}\text { Cor- } \\
\text { rected }\end{array}$ \\
\hline $\begin{array}{l}a \text { (St. Thomas's Group) } \\
b \text { (Rest of 93 hospitals) } \\
c \text { (Other hospitals) }\end{array}$ & $\begin{array}{r}1,722 \\
993 \\
110\end{array}$ & $\begin{array}{r}1,676 \\
838 \\
44\end{array}$ & $\begin{array}{r}500 \\
321 \\
67\end{array}$ & $\begin{array}{r}470 \\
239 \\
49\end{array}$ \\
\hline$\frac{a}{a+b}$ (Bailey's method) & 0.6342 & 0.6667 & 0.6090 & 0.6629 \\
\hline$\frac{a}{a+b+c}$ & 0.6096 & 0.6552 & 0.5631 & 0.6201 \\
\hline $5 N \frac{a}{a+b}(N=13,872)$ & 43,988 & 46,242 & 42,240 & 45,979 \\
\hline $5 N-\frac{a}{a+b+c}(N=13,872)$ & 42,282 & 45,445 & 39,057 & 43,010 \\
\hline
\end{tabular}

\section{Discussion}

The actual levels of hospital usage found, as shown in Tables I to III and X to XII, are of some interest, but because of the period of enquiry (just over six months) and the fact that information was not asked for about individual hospital episodes, it is difficult to find strictly comparable data from other sources. However, Ferguson and MacPhail (1954) showed that, of the population of two Scottish counties, $7 \cdot 29 \%$ had been in-patients and $11.06 \%$ out-patients during a period of 12 months shortly before the inception of the National Health Service. Their rate for out-patients is a good deal lower than those presented here, but the introduction of the National Health Service itself was responsible for a great increase in out-patient consultation. The United States National Health Survey (1965) showed that $9.3 \%$ of the population of the United States were likely to become in-patients during a period of 12 months. These figures should be compared with Tables III and XII.

The errors of reporting found are in the opposite direction from those reported by American studies. The United States National Health Survey (1961) found that persons tended to under-report their in-patient experience to the extent of about $10 \%$ of $\mathscr{O}$ all hospital stays. Similar tendencies to under-report have been found by Solon, Sheps, Lee, and Barbano (1962) and Haggerty (1965).

Discrepancies may be due either to report error $\underset{\vec{\rho}}{\vec{P}}$ or to record error. The former is the initially prefer- $\overrightarrow{0}$ able hypothesis, since the census questions were $\frac{\sigma}{6}$ answered from memory and frequently by a person $\frac{\bar{m}}{\bar{m}}$ other than the person concerned. On the other $\mathbb{\Phi}$ hand, this type of error is more likely to be in the direction of under-reporting, as in the American study, than of over-reporting. It is likely that a $\vec{\circ}$ person would omit to report a hospital episode $\overrightarrow{\vec{H}}$ because of failure to recall, or (if reporting for $\stackrel{\omega}{\sigma}$ another person) because he had not been told of it. $\frac{\Phi}{\circ}$ It is much less likely that he would 'invent' a hospital $\stackrel{\overbrace{}}{?}$ experience which had never occurred.

The possibility of record error must be considered. i This may consist of failure to record certain hospital $\mathscr{\vartheta}$ episodes, loss of notes concerning these episodes, or $\frac{\mathrm{O}}{\mathrm{T}}$ failure on the part of the searchers to find the record of these episodes. Little can be said as to the likeli- 3 hood of the first two types of error, but as regards the third it should be said that the records of all $\vec{\varphi}$ departments of the short-list hospitals were thob 8 oughly searched by members of this Departmen? and that the greatest possible co-operation was given by medical records officers, consultants in charge of special departments, and all staff concerned with medical records.

If report error is a major factor of the reportrecord discrepancy, certain trends with age and social class may be expected. Failure to recall accurately may be due either to failure of retention, or to lack of motivation to recall accurately, or to both. Poor retention is characteristic of the elderly, and poor motivation to co-operate with a social survey may be associated with lower social class. Table IX shows the proportion of persons classified 'correctly' (i.e., assigned to the same category of hospital usage by both report and record) in relation to sex, age, and social class; some superiority can be seen in the higher social classes and in the younger women, though not in the younger men. This may possibly indicate that reporting error is an important factor in producing discrepancy between report and record.

The above discussion of error is somewhat inconclusive and gives us no clear indication whether to prefer the statements of the census respondents or the medical records as the more accurate indication of actual hospital usage. We should, however, be reluctant to prefer answers given from memory to written records unless we have strong reasons for presuming the latter to be inaccurate. 
Taking response error into account, tentative conclusions can be drawn as to the value of the two methods of studying the demand for hospital services. The discrepancy between the figures estimated to be produced by Bailey's method, using a survey of 93 hospitals, and the records as found by the present study is considerably smaller than the discrepancy between records and reports in the present study. This would indicate that the Bailey method would be preferable even in a conurbation, apart from the need to survey a very large number of hospitals. This problem, however, may be overcome for some purposes by the use of the Hospital In-Patient Enquiry. The report for 1958 (Ministry of Health and General Register Office, 1961) contains an analysis of in-patients by district of residence and hospital at which treated, and such an analysis makes it possible to estimate the population served by any hospital, provided that the populations of districts are known. However, it is based on a $10 \%$ sample, is subject to some degree of inaccuracy in the drawing of the sample (Bennett, 1966), and does not analyse by speciality or diagnosis, so that Forsyth and Logan's (1960) procedure is not possible.

It seems likely that the best way of estimating hospital bed and service requirements in conurbations may be area-based rather than hospital-based, i.e., one should study a particular area and observe the demand for hospital services from the residents in that area without distinguishing between the hospitals by which this demand is satisfied. One may then arrive at reliable figures for the use of services in relation to population, and these services could then be provided at centres scattered according to the degree of specialities of the population and density of the population.

Such a procedure does not assume, as Bailey's does, that a hospital need always continue to serve to the same extent the precincts which it serves at present. It is a procedure oriented to regional planning, not to single-hospital demand forecasting.

\section{SUMMARY}

This study is an attempt to measure the hospital utilization of people living in a defined urban area. Results are presented of a house-to-house enquiry into hospital utilization of individuals residing in a random one-in-five sample of dwellings in North Lambeth, and are compared with those of a search of the appropriate hospital records.

In the period of enquiry (approximately six months) of the population of 13,903 persons aged $15 \frac{1}{2}$ or over, $81 \cdot 7 \%$ did not attend a hospital, $12.9 \%$ were out-patients only, $0.9 \%$ were in-patients only, and $4.3 \%$ were both in- and out-patients. Of the out-patients, $65.5 \%$ attended the St. Thomas's Group, $25.7 \%$ four other major hospitals, and the remainder attended 93 peripheral hospitals. Of the in-patients, $62.0 \%$ were admitted to the St. Thomas's Group, $14.4 \%$ to the four other major hospitals, and the remainder to the peripheral hospitals.

It is shown that older men use hospitals more than younger men but for women the highest in-patient usage is in the child-bearing years. There is a trend towards more hospital usage by the lower social classes. Men use peripheral hospitals more than women and those who use peripheral hospitals are more of social classes I and II.

Errors in the reporting of hospital utilization were found. In contrast to other experience of a tendency to under-report hospital in-patient experience, in general individuals tended to over-report. Analysis by age and social class revealed that the higher social classes and younger women reported more accurately, suggesting that reporting error is an important factor. Alternatively, some possibility remains of error in the search of hospital records. No conclusive explanation for this over-reporting was found. The effects of these errors are presented. This method of assessing hospital and bed-service requirements in a conurbation is compared with the method proposed by Bailey.

This study is part of a programme of studies supported by the Endowment Fund of St. Thomas's Hospital, the Ministry of Health, and the South-west Metropolitan Regional Hospital Board. We wish to thank the General Register Office, the Lambeth Borough Council, Dr. A. L. Thrower, Mr. S. G. Nicholas, and all members of the Department, including the medical and social science students who assisted in the collection of data. In particular we wish to thank all the many medical records officers and staff who so willingly assisted in the searching of medical records. Computer facilities were granted by Imperial College, London.

\section{REFERENCES}

BaILey, N. T. J. (1956). Statistics in hospital planning and design. Appl. Stat., 5, 146.

BennetT, A. E. (1966). Case selection in a London teaching hospital. Med. Care, 4, 138.

Ferguson, T., and MacPhail, A. N. (1954). Hospital and Community, p. 22. Oxford University Press, London.

FORSYTH, G., and LogAN, R. F. L. (1960). The Demand for Medical Care. A Study of the Case-load in the Barrow and Furness Group of Hospitals. Nuffield Provincial Hospitals Trust. Oxford University Press, London.

Haggerty, R. J. (1965). Family diagnosis. Amer. J. publ. Hlth, 55, 1521. 
Ministry of Health and General Register Office (1961). Report on Hospital In-Patient Enquiry for the Year 1958, Part II. H.M.S.O., London.

MONTGOMERY, K. M. (1968). Out-patients of a London teaching hospital. Brit. J. prev. soc. Med., 22, 50.

Nuffield Provincial Hospitals Trust. (1955). Studies in the Functions and Design of Hospitals. Oxford University Press, London.

Solon, J. A., Sheps, C. G., Lee, S. S., and Barbano, J. P. (1962). Patterns of medical care: validity of interview information on use of hospital clinics. $J$. Hlth hum. Behav., 3, 21.
United States National Health Survey (1961). Health Statistics, Series D, no. 4: Reporting of Hospitalization in the Health Interview Survey. U.S. Dept. of Health, Education and Welfare Public Health Service, Washing- ? ton, D.C.

(1965). Vital and Health Statistics, National Center for Health Statistics, Public Health Service Publ. No. 드 1000. Series 10, no. 20: Persons Hospitalized by के Number of Hospital Episodes and Days in a Year, United States-July 1960-June 1962. Washington, D.C. 